Research Article

\title{
Main Variables Affecting a Chemical-Enzymatic Method to Obtain Protein and Amino Acids from Resistant Microalgae
}

\author{
J. A. Callejo-López $\left(\mathbb{D},{ }^{1}\right.$ M. Ramírez $\mathbb{D}^{1},{ }^{1}$ J. Bolívar $\left(\mathbb{D},{ }^{2}\right.$ and D. Cantero ${ }^{1}{ }^{1}$ \\ ${ }^{1}$ Department of Chemical Engineering and Food Technology, Vitivinicultural and Agri-Food Research Institute (IVAGRO), \\ University of Cadiz, Puerto Real 11510, Spain \\ ${ }^{2}$ Department of Biomedicine Biotechnology and Public Health, Institute of Biomolecules (INBIO), University of Cadiz, \\ Puerto Real 11510, Spain \\ Correspondence should be addressed to M. Ramírez; martin.ramirez@uca.es
}

Received 31 December 2018; Revised 27 March 2019; Accepted 7 April 2019; Published 28 April 2019

Academic Editor: Gerald Culioli

Copyright (c) 2019 J. A. Callejo-López et al. This is an open access article distributed under the Creative Commons Attribution License, which permits unrestricted use, distribution, and reproduction in any medium, provided the original work is properly cited.

\begin{abstract}
The development of microalgae uses requires further investigation in cell disruption alternatives to reduce the costs associated to this processing stage. This study aimed to evaluate the main variables affecting an extraction method to obtain protein and amino acids from microalgae. The method was based on a sequential alkaline-enzymatic process, with separate extractions and noncontrolled $\mathrm{pH}$, and was applied to fresh biomass of a resistant species. The processed microalgae were composed of a consortium with Nannochloropsis sp. as predominant species. After the optimization of the $\mathrm{pH}$ of the alkaline reaction, the effect of the time of the alkaline reaction (30-120 $\mathrm{min})$, the time $(30-120 \mathrm{~min})$ and temperature $\left(40-60^{\circ} \mathrm{C}\right)$ of the enzymatic reaction, and the biomass concentration $\left(50-150 \mathrm{mg} \cdot \mathrm{ml}^{-1}\right)$, on the extraction yields of protein and free amino nitrogen (FAN) and on the final concentration of protein in the extract, was studied using a response surface methodology. Even though all the variables and some interactions among them had a significant effect, the biomass concentration was the most important factor affecting the overall process. The results showed relevant information about the different options in order to maximize not only the response variables individually but also different combinations of them. Assays with optimized values reached maximum yields of $80.3 \%$ and $1.07 \%$ of protein (\% of total protein) and FAN (\% of total biomass), respectively, and a protein concentration in the extract of $15.2 \mathrm{mg} \cdot \mathrm{ml}^{-1}$. The study provided the essential information of an alternative approach to obtain protein and amino acids from fresh biomass of resistant microalgae with a high yield, also opening perspectives for further research in particular aspects.
\end{abstract}

\section{Introduction}

Microalgae have a huge benefit as resource to supply the increasing demand of protein and amino acids for food and feed [1], biofertilizers and biostimulants [2], bulk chemicals [3], and bioactives [4]. Nevertheless, economic constraints have hampered the development of these applications, which in general have limited microalgae uses to high-value bioproducts [5-7]. These restrictions are due to mainly the high energetic and economic costs of some stages of the industrial processes, such as harvesting, drying, and cellular disruption [8-10].

With regard to disruption, the selection of the method depends on the cell wall resistance of the species used and the target molecules, as well as on economic and environmental aspects. Concerning the hardness of the method, it is necessary to reach a compromise between obtaining an acceptable yield and reducing the possible damage of the target bioproduct. In the case of proteins and amino acids, even though it is preferable to use mild methods, sometimes they are not hard enough to disrupt the cell wall and release most of the intracellular molecules, giving rise to low extraction yields, especially from recalcitrant organisms [11]. In particular, microalgae species with resistant cell wall are more suitable to be used in integrated depuration processes to recover residual nutrients, due to their natural resistance against adverse environments. Furthermore, low-cost applications of microalgae require the use of fresh biomass to 
avoid the previous costly drying even though microorganisms preserve their cell wall intact, which hinder the bioproducts recovering. Disruption techniques such as bead milling and high-pressure homogenization have demonstrated to be very effective and relatively energy-efficient methods $[12,13]$ though they require specific equipment for which inversion costs are only feasible for some applications [8-10]. In contrast, from an operational point of view, alkaline and/or enzymatic methods could be characterized by their simplicity and therefore applicable to low-cost uses.

Concerning alkaline methods, previous researches have demonstrated that high alkalinities induce cell wall weakening and protein extraction from microalgae [14-16]. Furthermore, enzymatic assisted methods based on proteases enhance the extraction and amino acid production from microalgae biomass $[3,17]$. Nevertheless, the combined effect of an alkaline extraction followed by an enzymatic one has not been studied extensively.

This study aimed to evaluate the main variables affecting an extraction method consisting in a sequential alkalineenzymatic process, with separate extractions and non-pH controlled, to obtain protein and amino acids from fresh biomass of resistant microalgae, avoiding additional disruption pretreatments or drying. The process includes two sequential reactions/extractions: an alkaline reaction for cell disruption and first extraction of proteins, followed by an enzymatic reaction with a commercial protease, for further extraction, and the hydrolysis of the released proteins. The evaluation was performed using a microalgae consortium composed by Nannochloropsis sp. as predominant species. Firstly, the optimal $\mathrm{pH}$ of the alkaline extraction was established. Subsequently, the main variables of the process were evaluated through a statistical analysis of response surface with a face-centered central composite design (CCD).

\section{Materials and Methods}

2.1. Microalgae and Cultivation. Microalgae consortium, nonaxenic, was obtained from the Department of Chemical Engineering and Food Technologies, Faculty of Sciences, University of Cádiz. This consortium was isolated in a previous research from a leachate of the landfill "Miramundo-Los Hardales" (Biorreciclaje de Cádiz S.A., Spain). The predominant species was identified by morphologic evaluation, which belongs to the genera of Nannochloropsis sp.

Cultures were grown in $5 \mathrm{~L}$ borosilicate glass bottles under constant led light $\left(170 \mu \mathrm{mol}\right.$ photons $\mathrm{m}^{-2} \cdot \mathrm{s}^{-1}$ average surface irradiance), 12/12 $\mathrm{h}$ photoperiod, and room temperature controlled by an air conditioner $\left(23-26^{\circ} \mathrm{C}\right)$. Carbon source, as pure $\mathrm{CO}_{2}$, was bubbled by mixing with air into the photobioreactors from the bottom, previously filtered through $0.22 \mu \mathrm{m}$ filters (SLG0510, Merck Millipore, Germany). $\mathrm{CO}_{2}$ proportion of the mix $\left(5-10 \% \mathrm{v} \cdot \mathrm{v}^{-1}\right)$ was established on function of the culture $\mathrm{pH}$, between 7.5 and 7.8. Air was introduced at a flow rate of $0.1 \mathrm{vvm}$. Nutrients were supplied using Combo medium [18], enriched in nitrogen $(10 \mathrm{mM})$ and phosphorus $(0.5 \mathrm{mM})$, providing an excess of these nutrients to maximize protein content in the biomass. Cultures were carried out in the discontinue mode for 7 days and a maximum concentration of biomass between 0.7 and $0.8 \mathrm{~g} \cdot \mathrm{l}^{-1}$, harvesting in exponential growth phase.

The microalgae biomass was concentrated by centrifugation at $5,000 \mathrm{~g}$ for $15 \mathrm{~min}$ and $4^{\circ} \mathrm{C}$. To wash the biomass of residual nutrients and salts, this procedure was repeated 2 times resuspending the centrifuged paste in distilled water. The evaluation of the method proposed in this study was performed with the biomass immediately obtained after this procedure (hereafter, referred to as fresh biomass). In addition, dry biomass was produced for analysis of total nitrogen and amino acids content. For these cases, centrifuged paste was frozen at $-80^{\circ} \mathrm{C}$ and freeze-dried (Lyoalfa-85 $3.5 \mathrm{~kW}$, Telstar, Spain).

\subsection{Experimental Setup}

2.2.1. Experimental Procedure. Experiments were performed with suspensions of fresh biomass prepared from centrifuged paste obtained directly from cultures as described above. The required concentrations of the suspensions, calculated in a dry weight basis, were adjusted by dilution of the paste with buffered solutions at different $\mathrm{pH}$ depending on the assay, as specified subsequently. Dry weight of the biomass was determined in each experiment by drying in an oven at $105^{\circ} \mathrm{C}$ for $24 \mathrm{~h}$ by the Standard Method 10200 I.5 [19].

The assays were performed in $2 \mathrm{ml}$ centrifugal tubes, in an orbital incubator at $150 \mathrm{rpm}$, under the temperatures and times specified subsequently in function of the experiment. The first alkaline extraction was performed by incubating the suspension in alkaline buffered solutions at different $\mathrm{pH}$ values and $50^{\circ} \mathrm{C}$. At the end of the selected reaction times, the supernatants were recovered by centrifugation at $10,000 \times g$ for further analysis (alkaline extracts) and the pellet was kept for the subsequent enzymatic reaction. This pellet was immediately resuspended in $100 \mathrm{mM}$ Tris- $\mathrm{HCl}$ at $\mathrm{pH} 8$, diluting till it reaches the initial volume used in the alkaline reaction. Subsequently, the enzymatic reaction was carried out by incubating with Alcalase ${ }^{\circledR}$ 2.5L (Novozymes Spain, S.A., Spain) at different temperatures and times, using an enzyme dosage of $0.2 \mathrm{ml} \cdot \mathrm{g}^{-1}$. The reactions were stopped by inactivating the enzymes at $85^{\circ} \mathrm{C}$ for $10 \mathrm{~min}$. Subsequently, supernatants were recovered by centrifugation at $10,000 \times g$ for further analysis (enzymatic extracts), and the pellets were discarded. Both alkaline and enzymatic extracts were frozen and stored at $-20^{\circ} \mathrm{C}$ until their analysis.

The buffered solutions used in the assays consisted of $\mathrm{pH}$ 8 (100 mM Tris- $\mathrm{HCl}), \mathrm{pH} 10\left(50 \mathrm{mM} \mathrm{Na}_{2} \mathrm{CO}_{3}\right), \mathrm{pH} 11$ $\left(50 \mathrm{mM} \mathrm{Na}_{2} \mathrm{CO}_{3}\right)$, and $\mathrm{pH} 12\left(50 \mathrm{mM} \mathrm{Na}_{2} \mathrm{HPO}_{4}\right)$. These $\mathrm{pH}$ values correspond to the final values obtained by titration with $\mathrm{NaOH}$ or $\mathrm{HCl}$ at $25^{\circ} \mathrm{C}$. A solution at $\mathrm{pH} 13.4$ was used in high alkaline treatment, obtained by titration with $\mathrm{NaOH}$ of a $50 \mathrm{mM} \mathrm{Na}_{2} \mathrm{HPO}$ solution. Since the $\mathrm{p} K_{\mathrm{a}}$ of the phosphate buffer system $\left(\mathrm{HPO}_{4}{ }^{2-} / \mathrm{PO}_{4}{ }^{3-}\right)$ is 12.33 , the maximum theoretical buffering capacity achieved was $\mathrm{pH} 13.33$ [20]. Therefore, the solution at $\mathrm{pH} 13.4$ used in the high alkaline 
treatments was slightly above to this maximum buffering capacity. In the case of the enzymatic-buffered solution at $\mathrm{pH} 8$, a higher strength $(100 \mathrm{mM})$ was selected due to the higher acidification expected in the enzymatic reaction as a consequence of the protein hydrolysis.

2.2.2. Effect of the $p H$ of the First Alkaline Reaction. The effect and optimization of the $\mathrm{pH}$ of the first alkaline reaction were performed with an assay that consisted of (i) the alkaline reaction at five different $\mathrm{pH}$ values using the buffered solutions at $\mathrm{pH} 8,10,11,12$, and 13.4 for $1 \mathrm{~h}$ and (ii) the enzymatic reaction with Alcalase ${ }^{\circledR}$ at $0.2 \mathrm{ml} \cdot \mathrm{g}^{-1}$ of dry biomass for $3 \mathrm{~h}$ with the buffer solution at $\mathrm{pH}$. Both reactions were carried out at $50^{\circ} \mathrm{C}$ and $150 \mathrm{rpm}$, using a biomass concentration of $20 \mathrm{mg} \cdot \mathrm{ml}^{-1}$. Blanks were subjected to two sequential extractions at $\mathrm{pH}$, without protease in the second extraction, at the same temperature and reaction times. pH 13.4 was selected as optimal of the high alkaline treatment based on preliminary experiments, in which a range of $\mathrm{pH}$ from 13.0 to 13.7 was evaluated (data not shown).

\subsubsection{Effect of the Main Variables Affecting the Process.} The main variables of the sequential process were evaluated using a statistical analysis of response surface with a facecentered CCD: $2^{4}$ (factorial design), three replications of the centre point, and eight star points $(\alpha=1)$. The variables considered were the time of the alkaline reaction $\left(t_{\mathrm{a}}\right)$, the time $\left(t_{\mathrm{e}}\right)$ and temperature $\left(T_{\mathrm{e}}\right)$ of the enzymatic reaction, and the concentration of the biomass $\left(B_{\mathrm{c}}\right)$. Factor levels of these variables were selected to cover the range of the optimal expected according to preliminary assays and trying to reduce the impact of the high energetic and economic demanding factors, such as the reaction times (maximum $2 \mathrm{~h}$ ) and temperatures (maximum $60^{\circ} \mathrm{C}$ ). In the case of the biomass concentration, a maximum of $150 \mathrm{mg} \cdot \mathrm{ml}^{-1}$ was chosen. The range and the levels of the variables are given in Table 1.

Response variables studied were the total yields of the two sequential extractions of protein, expressed as the percentage of the total protein content in the biomass (\% of total protein), and free amino nitrogen (FAN), as percentage of the biomass (\% of biomass). Additionally, protein content in the extract $\left(\mathrm{mg} \cdot \mathrm{ml}^{-1}\right)$ was considered as the response variable in combined optimizations from the different variables. The design of experiments and the analysis of results were carried out with the statistical software Statgraphics Centurion XVII (Statpoint Technologies, Inc., USA).

The experimental results were fitted with the following second-order polynomial equation:

$$
y=\beta_{0}+\sum_{i=1}^{n} \beta_{i} x_{i}+\sum_{i=1}^{n} \beta_{i i} x_{i}^{2}+\sum_{i=1}^{n-1} \sum_{j=i+1}^{n} \beta_{i j} x_{i} x_{j},
$$

where $y$ represents the response variable, $\beta_{0}$ is the interception coefficient, $\beta_{\mathrm{i}}, \beta_{i}$, and $\beta_{i j}$ are the linear, quadratic, and interaction regression coefficients, respectively, $n$ is the
TABLE 1: Levels of the factors in the experimental design according to the face-centered CCD.

\begin{tabular}{lcccc}
\hline \multirow{2}{*}{ Factor } & \multirow{2}{*}{ Unit } & \multicolumn{3}{c}{ Factor level } \\
& & -1 & 0 & 1 \\
\hline Time of the alkaline reaction $\left(t_{\mathrm{a}}\right)$ & $\mathrm{min}$ & 30 & 75 & 120 \\
Time of the enzymatic reaction $\left(t_{\mathrm{e}}\right)$ & $\mathrm{min}$ & 30 & 75 & 120 \\
Temperature of the enzymatic & ${ }^{\circ} \mathrm{C}$ & 40 & 50 & 60 \\
reaction $\left(T_{\mathrm{e}}\right)$ & $\mathrm{mg} \cdot \mathrm{ml}^{-1}$ & 50 & 100 & 150 \\
Biomass concentration $\left(B_{\mathrm{c}}\right)$ & & & & \\
\hline
\end{tabular}

number of studied variables, and $x_{\mathrm{i}}$ and $x_{j}$ represent the independent variables.

2.2.4. Validation of the Optimized Conditions. Experiments were carried out using the optimized conditions to confirm and validate models obtained from the analysis of the response surface.

\subsection{Analytical Methods}

2.3.1. Determination of Total Protein, Total Nitrogen, and Amino Acid Composition. Total protein content of the microalgae consortium was calculated from total nitrogen, multiplied by a nitrogen-to-protein conversion factor obtained from the analysis of the amino acids composition, determined as described below. The nitrogen-to-protein conversion factor $(k)$ was calculated according to Mossé [21], as the average between the upper limit $k_{\mathrm{A}}$ and the lower limit $k_{\mathrm{p}}$.

Total nitrogen content was determined by elementary analysis (Leco ${ }^{\circledR}$ CHNS 932, Leco Corporation, USA), using the combustion Dumas method [22].

Amino acids composition analysis was performed by high-performance liquid chromatography (HPLC), after $24 \mathrm{~h}$ hydrolysis with $6 \mathrm{~N} \mathrm{HCl}$ at $110^{\circ} \mathrm{C}$, and phenylsiothiocyanate (PICT) derivatisation according to Heinrikson and Meredith [23]. In brief, after the centrifugation of the acid hydrolysate, the supernatant was filtered through an Amicon Ultra-0.5 ml Ultracel-10K centrifugal filter (Merck Millipore, Germany) for deproteinization. The samples were mixed with the derivatizing solution (ethanol: $\mathrm{H}_{2} \mathrm{O}$ : triethanolamine:PITC, $7: 1: 1: 1)$, incubated at room temperature for $30 \mathrm{~min}$, and dried under flowing $\mathrm{N}_{2}$. The pellet was resuspended in $4 \mathrm{mM}$ sodium phosphate ( $\mathrm{pH} 7.4$ ) and $2 \%$ acetonitrile and injected in a HPLC LaChrom Elite ${ }^{\circledR}$ (Hitachi, Japan) system. The separation was performed using a LIchroCART 125-4 column. Amino acids were separated using a linear gradient from $70 \mathrm{mM}$ sodium acetate and 5\% acetonitrile buffer ( $\mathrm{pH} 6.55)$ to acetonitrile/water $(50: 50)$.

Ammonia was determined separately by ion chromatography (Metrohm 930 Compact IC Flex, Switzerland) with a pulse amperometric detector with a gold electrode as the working electrode. The elution was carried out in isocratic at a $0.9 \mathrm{ml} \mathrm{min}^{-1}$ flow rate with $1.7 \mathrm{mM} \mathrm{HNO}_{3}$ and $1.0 \mathrm{mM}$ dipiconilic acid. The separation was performed using a Metrosep C 6-250/4.0 column. 
2.3.2. Determination of Soluble Proteins, Peptides, and Free Amino Acids. Soluble protein in alkaline extracts was determined by the Lowry method [24], following the modifications of Bensadoun and Weinstein [25] to remove potential interfering substances. According to the last, proteins of the samples were precipitated with sodium deoxycholate (2\%) and trichloroacetic acid (TCA) (24\%), by centrifugation at $10,000 \times g$ for $20 \mathrm{~min}$ (TCA-Lowry). The standard curve was prepared using bovine serum albumin precipitated following the same procedure. Absorbance was measured at $750 \mathrm{~nm}$ using a microplate reader (Multiskan FC, Thermo Fisher Scientific Inc., USA) in 96-well plates.

The soluble proteinaceous material in enzymatic extracts was determined separately among peptides and free amino acids (and small peptides, which are not detected by the Lowry method). Peptides were determined through the conventional Lowry method, applying a correction factor to take into account potential interfering substances, instead of using TCA precipitation since a large part of them are lost in this precipitation. The correction factor considered was equal to the interference produced in the first alkaline extraction and was calculated dividing the protein determined in the alkaline samples using the TCA-Lowry procedure by the protein determined using conventional Lowry, in each individual experiment.

Free amino acids and small peptides were calculated from the nitrogen determined by FAN analysis using the ninhydrin colorimetric method [26], multiplied by a nitrogen-to-amino acid conversion factor of 5.9. This conversion factor was calculated from amino acids composition analysis (described above) of the alkaline and enzymatic extracts. In the ninhydrin determination, glycine was used as standard and the absorbance was measured at $570 \mathrm{~nm}$ using the microplate reader mentioned above. The protein and amino acid weights of the protease used in the enzymatic extractions were subtracted from the results.

2.4. Statistical Analysis of Data. The results were analysed by one-way analysis of variance (ANOVA) with a significance level of $p$ value equal to 0.05 , followed by Tukey's multiple comparison test, where applicable. Each experiment was carried out in triplicate, if not stated otherwise. Mean values and standard deviation (SD) are reported.

\section{Results and Discussion}

3.1. Total Protein. The total protein content of the microalgae consortium was $39.5 \%$ of the biomass (dry weight basis). This value was obtained from total nitrogen content in the biomass of $8.93 \%$, multiplied by a nitrogen-to-protein conversion factor of 4.43 . The conversion factor is within the range of previously reported values $[27,28]$.

3.2. Effect of $\mathrm{pH}$ of First Alkaline Extraction. Effect of $\mathrm{pH}$ of the first alkaline reaction in the sequential process was studied to establish its optimal value and to reduce study variables of subsequent experiments. Figure 1 shows the $\mathrm{pH}$ effect in protein extraction yield (proteinaceous material)

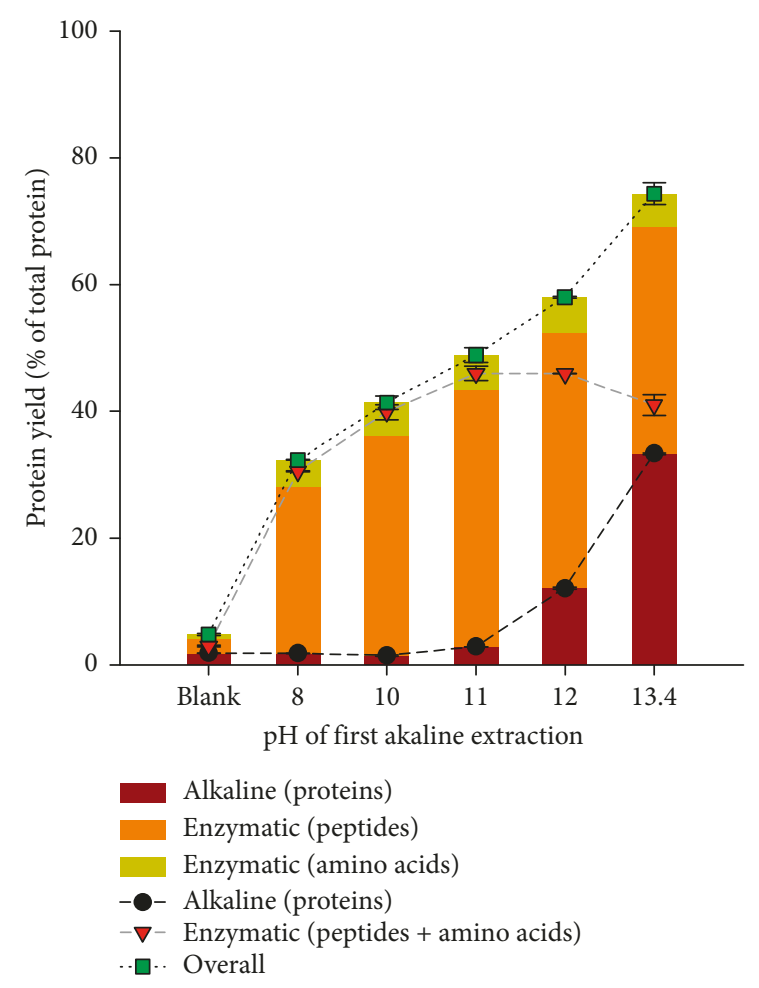

FIGURE 1: Effect of the $\mathrm{pH}$ of the first alkaline extraction on protein extraction yield (\% of total protein) differencing among the two sequential alkaline and enzymatic extractions. The stacked bars represent the partial results obtained in the first alkaline extraction (proteins) and the second enzymatic extraction (differencing among peptides and amino acids). The lines represent the tendency of the same partial results and overall.

differencing among the first alkaline and the second enzymatic sequential extractions, as well as in the overall process (sum of the two extractions).

In relation to the first alkaline extraction, yields were statistically significantly different among the $\mathrm{pH}$ values studied $(p$-value $<0.0001)$. Multiple comparisons among means showed significantly different yields with respect to control at $\mathrm{pH}$ values equal or higher than 11 even though the effect of alkaline treatment was not notable up to $\mathrm{pH} \mathrm{12,}$ where the yield achieved $12.1 \%$ of total protein, compared to the low value obtained at $\mathrm{pH} 11$ (2.9\%). Nevertheless, the highest value by far was obtained at $\mathrm{pH} 13.4$, with an extraction yield of $33.3 \%$ of total protein.

In relation to the second enzymatic extraction, results were also statistically significantly different ( $p$ value $<0.0001)$ among the alkalinities tested in the previous alkaline phase. In particular, extraction yield increased from $\mathrm{pH} 8(30.5 \%)$ to $\mathrm{pH} 11(46.0 \%)$ of the previous alkaline extraction, with statistically significant differences among them. Above $\mathrm{pH} 11$, enzymatic extraction did not improve due to the fact that most of the proteins were extracted in the previous alkaline phase, being the yield at this $\mathrm{pH}$ statistically similar to $\mathrm{pH} 12(45.9 \%)$ and even higher than at $\mathrm{pH}$ $13.4(41.0 \%)$. The increase of yields observed in the enzymatic extraction with the $\mathrm{pH}$ of the first alkaline extraction-at least from $\mathrm{pH} 8$ to 11 -suggests that higher 
alkalinities improve subsequent extraction of proteinaceous material in the second enzymatic step, probably as a result of the cell wall weakening induced by the previous alkaline treatment.

Considering the overall process, the increase of the total yields with the $\mathrm{pH}$ of the first alkaline extraction was remarkable, comprising from $32.4 \%$ obtained at the low $\mathrm{pH}$ value ( $\mathrm{pH} 8)$ up to $74.3 \%$ in the high alkaline treatment $(\mathrm{pH}$ 13.4), being all the treatments significantly different among them in multiple comparisons.

In relation to previous studies, using alkaline methods, Gerde et al. [29] obtained similar results at $\mathrm{pH} 9$ and 11 (2\%) with Nannocloropsis sp., and slightly lower at pH 13 (24.2\%), compared with the $33.3 \%$ obtained in our study at 13.4 , which would be mainly due to a difference of 0.4 in the $\mathrm{pH}$ applied. That experiment was performed at $60^{\circ} \mathrm{C}$ using a non-pH controlled process, over microalgae biomass obtained as frozen paste, which was subsequently defatted and air-dried. Safi et al. [30] obtained higher yields at $\mathrm{pH} \mathrm{12,} \mathrm{of} 31.1$ and $33.2 \%$ with Nannocloropsis oculata and Chlorella vulgaris, respectively, at $40^{\circ} \mathrm{C}$ for $2 \mathrm{~h}$. Those high values with respect to those obtained in our study of $12.1 \%$ could be due to the form of initial biomass used, which was freeze-dried biomass of a commercial algae previously purchased as frozen paste. Additionally, Sari et al. [3] achieved higher extraction yields at $\mathrm{pH} 10$ (35\%) with Chlorella fusca $\left(60^{\circ} \mathrm{C}\right.$ for $\left.3 \mathrm{~h}\right)$ even though using a $\mathrm{pH}$-controlled process and biomass not directly obtained from cultures. Gerde et al. [29] also improved considerably in their alkaline extraction through a $\mathrm{pH}$ controlled process at $\mathrm{pH} 11$ for $5 \mathrm{~h}$ up to $16 \%$ and $30 \%$, with defatted and non-defatted biomass, respectively.

It is worth to note that the low extraction achieved in the alkaline reactions between $\mathrm{pH} 8$ and $\mathrm{pH} 12$ at $50^{\circ} \mathrm{C}$ for $1 \mathrm{~h}$ and the second extraction of the blank at $50^{\circ} \mathrm{C}$ for $3 \mathrm{~h}$, as well as in the enzymatic extraction at $\mathrm{pH} 8(30.5 \%)$, confirms the recalcitrant character of the algae consortium used. Indeed, Safi et al. [31] reached a similar yield (35\%) with Nannochloropsis gaditana, a recognized resistant microalgae [32], through an enzymatic reaction using the same protease of this study (Alcalase).

As a result of this assay, $\mathrm{pH} 13.4$ was selected as the optimal $\mathrm{pH}$ for the alkaline reaction in the subsequent experiment. The high alkaline treatment performed demonstrated being capable of extracting proteins with a high yield, as well as to weaken the cell wall of recalcitrant microalgae for further enzymatic extraction of the proteinaceous material. In most of the previous researches, high alkaline extraction methods were not studied since the combination of heating and alkaline treatments can modify the protein properties due to denaturation, racemization, and lysinoalanine formation [33], making them nonsuitable for some applications. In our study, we selected this very high alkaline treatment with the aim to investigate this alternative for maximizing nitrogen recovery from recalcitrant microalgae using fresh biomass, as a mean to obtain a possible low-cost resource of these bioproducts for many potential applications. For these applications, proteins and amino acids obtained by the method proposed in this study will need further investigation.
3.3. Effect of Main Variables of the Sequential Process. Once established the optimal $\mathrm{pH}$ of the alkaline reaction at 13.4, an analysis to evaluate the effect of the main variables involved in the sequential process was performed using a response surface methodology analysis by a face-centered CCD. After the identification of the terms affecting the models, the results were adjusted to fit to second-order equations for both protein and FAN yields, considering the most relevant interactions among the factors. Even though some terms were not statistically significant ( $p$-value $<0.05)$, they were maintained in the equations to reduce the impact in the $R^{2}$ coefficient. The equations with the coefficient obtained were

$$
\begin{aligned}
\text { protein yield (\% of total protein) }= & 56.3+0.325 * t_{\mathrm{a}}-0.194 \\
& * B_{\mathrm{c}}+0.133 * T_{\mathrm{e}} \\
& +0.0251 * t_{\mathrm{e}}-0.0014 \\
& * t_{\mathrm{a}}^{2}-0.000722 * t_{\mathrm{a}} * B_{\mathrm{c}} \\
& +0.00102 * t_{\mathrm{a}} * T_{\mathrm{e}} \\
& -0.00033 * B_{\mathrm{c}}^{2} \\
& +0.000559 * B_{\mathrm{c}} * t_{\mathrm{e}}, \\
\text { FAN yield (\% of total biomass) }= & -1.06+0.0035 * t_{\mathrm{a}} \\
& +0.00555 * B_{\mathrm{c}}+0.0442 \\
& * T_{\mathrm{e}}-0.000203 * t_{\mathrm{e}} \\
& -0.0000215 * t_{\mathrm{a}}^{2} \\
& +0.00000757 * t_{\mathrm{a}} * B_{\mathrm{c}} \\
& -0.0000343 * B_{\mathrm{c}}^{2} \\
& +0.0000343 * B_{\mathrm{c}} * T_{\mathrm{e}} \\
& +0.0000281 * B_{\mathrm{c}} * t_{\mathrm{e}} \\
& -0.000426 * T_{\mathrm{e}}^{2} .
\end{aligned}
$$

Both protein and FAN model equations notably suited to the data according to the statistical coefficients obtained. The regression coefficients $R^{2}$ were 0.991 and 0.981 for proteins and FAN yields, respectively (adjusted- $R^{2}=0.985$ and 0.969), indicating that the model explains $99.1 \%$ and $98.1 \%$ of the dependent variability of the variables. The results obtained in the experiments and the values predicted by the models are displayed in Table 2. The comparison among observed and predicted data shows a notable fit for both protein and FAN models.

Table 3 shows the statistical significance of the variables of the models, revealed by its $p$ values. In the protein model, all the effects studied, as well as the interactions among the biomass concentration with the times of the both alkaline and enzymatic reactions, had a $p$ value lower than 0.05 , indicating that their effects were significant with a confidence level of $95.0 \%$. Additionally, the quadratic term of the time of the alkaline reaction was significant. For FAN, all effects studied were also significant and the interaction between the biomass concentration and the time of the 
TABLE 2: Experimental design and results of the face-centered CCD.

\begin{tabular}{ccccccccc}
\hline & & & & \multicolumn{3}{c}{$\begin{array}{c}\text { Protein (\% of total } \\
\text { protein) }\end{array}$} & \multicolumn{2}{c}{$\begin{array}{c}\text { FAN } \\
\text { biomass) }\end{array}$} \\
Run & $t_{\mathrm{a}}$ & $B_{\mathrm{c}}$ & $T_{\mathrm{e}}$ & $t_{\mathrm{e}}$ & \multicolumn{2}{c}{ of total } \\
& & & & & Observed & Predicted & Observed & Predicted \\
\hline 1 & -1 & -1 & -1 & -1 & 61.47 & 61.36 & 0.44 & 0.43 \\
2 & +1 & -1 & -1 & -1 & 71.18 & 72.14 & 0.50 & 0.48 \\
3 & -1 & -1 & -1 & +1 & 66.84 & 66.13 & 0.52 & 0.53 \\
4 & +1 & -1 & -1 & +1 & 79.13 & 76.91 & 0.58 & 0.59 \\
5 & 0 & 0 & -1 & 0 & 57.81 & 59.17 & 0.76 & 0.78 \\
6 & -1 & +1 & -1 & -1 & 35.68 & 34.85 & 0.53 & 0.54 \\
7 & +1 & +1 & -1 & -1 & 40.26 & 39.13 & 0.72 & 0.67 \\
8 & -1 & +1 & -1 & +1 & 43.21 & 44.65 & 0.91 & 0.90 \\
9 & +1 & +1 & -1 & +1 & 47.87 & 48.93 & 0.97 & 1.03 \\
10 & 0 & -1 & 0 & 0 & 73.26 & 74.07 & 0.61 & 0.63 \\
11 & -1 & 0 & 0 & 0 & 55.64 & 54.21 & 0.78 & 0.78 \\
12 & +1 & 0 & 0 & 0 & 61.85 & 62.66 & 0.86 & 0.87 \\
13 & 0 & 0 & 0 & -1 & 56.51 & 57.63 & 0.70 & 0.75 \\
14 & 0 & 0 & 0 & +1 & 65.52 & 64.92 & 1.06 & 0.99 \\
15 & 0 & 0 & 0 & 0 & 62.37 & 61.27 & 0.87 & 0.87 \\
16 & 0 & 0 & 0 & 0 & 60.39 & 61.27 & 0.88 & 0.87 \\
17 & 0 & 0 & 0 & 0 & 60.03 & 61.27 & 0.84 & 0.87 \\
18 & 0 & +1 & 0 & 0 & 48.24 & 46.83 & 0.95 & 0.94 \\
19 & -1 & -1 & +1 & -1 & 65.72 & 64.64 & 0.49 & 0.49 \\
20 & +1 & -1 & +1 & -1 & 77.85 & 77.25 & 0.56 & 0.55 \\
21 & -1 & -1 & +1 & +1 & 67.36 & 69.41 & 0.59 & 0.60 \\
22 & +1 & -1 & +1 & +1 & 81.14 & 82.03 & 0.67 & 0.66 \\
23 & 0 & 0 & +1 & 0 & 65.67 & 63.37 & 0.88 & 0.88 \\
24 & -1 & +1 & +1 & -1 & 36.61 & 38.13 & 0.64 & 0.67 \\
25 & +1 & +1 & +1 & -1 & 43.52 & 44.24 & 0.81 & 0.80 \\
26 & -1 & +1 & +1 & +1 & 48.79 & 47.93 & 1.05 & 1.04 \\
27 & +1 & +1 & +1 & +1 & 54.55 & 54.05 & 1.15 & 1.16 \\
\hline & & & & & & & &
\end{tabular}

TABLE 3: Regression coefficients, $\mathrm{F}$ values, and $p$ values of the variables and interactions in the equation models.

\begin{tabular}{|c|c|c|c|}
\hline Term & Coefficient & $F$ value & $p$ value \\
\hline \multicolumn{4}{|c|}{ Protein } \\
\hline Intercept & 56.3 & - & - \\
\hline A: $t_{\mathrm{a}}$ & 0.325 & 138.21 & $<0.0001^{\mathrm{a}}$ \\
\hline B: $B_{\mathrm{c}}$ & -0.194 & 1437.9 & $<0.0001^{\mathrm{a}}$ \\
\hline $\mathrm{C}: T_{\mathrm{e}}$ & 0.133 & 34.13 & $<0.0001^{\mathrm{a}}$ \\
\hline $\mathrm{D}: t_{\mathrm{e}}$ & 0.0251 & 102.9 & $<0.0001^{\mathrm{a}}$ \\
\hline$t_{\mathrm{a}} \times t_{\mathrm{a}}$ & -0.0014 & 11.54 & $0.0034^{\mathrm{a}}$ \\
\hline$t_{\mathrm{a}} \times B_{\mathrm{c}}$ & -0.000722 & 18.19 & $0.0005^{\mathrm{a}}$ \\
\hline$t_{\mathrm{a}} \times T_{\mathrm{e}}$ & 0.00102 & 1.45 & 0.2448 \\
\hline$B_{\mathrm{c}} \times B_{\mathrm{c}}$ & -0.00033 & 0.98 & 0.3371 \\
\hline$B_{\mathrm{c}} \times t_{\mathrm{e}}$ & 0.000559 & 10.89 & $0.0042^{\mathrm{a}}$ \\
\hline \multicolumn{4}{|c|}{ FAN } \\
\hline Intercept & -1.06 & - & - \\
\hline $\mathrm{A}: t_{\mathrm{a}}$ & 0.0035 & 33.32 & $<0.0001^{\mathrm{a}}$ \\
\hline B: $B_{\mathrm{c}}$ & 0.00555 & 362.94 & $<0.0001^{\mathrm{a}}$ \\
\hline $\mathrm{C}: T_{\mathrm{e}}$ & 0.0442 & 39.25 & $<0.0001^{\mathrm{a}}$ \\
\hline $\mathrm{D}: t_{\mathrm{e}}$ & -0.000203 & 209.15 & $<0.0001^{\mathrm{a}}$ \\
\hline$t_{\mathrm{a}} \times t_{\mathrm{a}}$ & -0.0000215 & 4.49 & 0.0501 \\
\hline$t_{\mathrm{a}} \times B_{\mathrm{c}}$ & 0.00000757 & 3.94 & 0.0647 \\
\hline$B_{c} \times B_{c}$ & -0.0000343 & 17.4 & $0.0007^{\mathrm{a}}$ \\
\hline$B_{\mathrm{c}} \times T_{\mathrm{e}}$ & 0.0000343 & 3.98 & 0.0635 \\
\hline$B_{\mathrm{c}} \times t_{\mathrm{e}}$ & 0.0000281 & 54 & $<0.0001^{\mathrm{a}}$ \\
\hline$T_{\mathrm{e}} \times T_{\mathrm{e}}$ & -0.000426 & 4.3 & 0.0546 \\
\hline
\end{tabular}

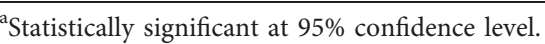

enzymatic reaction, as well as the quadratic term of the biomass concentration, was also significant.

Pareto diagrams showed in Figure 2 represent graphically the standardized effects of the variables and interactions. In both protein and FAN models, the concentration of the biomass was the main variable affecting the global process. Nevertheless, in protein yield, the effect of the biomass concentration was negative and in FAN was positive.

In the case of proteins, the negative effect of biomass concentration was probably caused by the dilution of the alkaline medium by the biomass volume at the higher biomass concentrations. This would lead to a significant drop of the $\mathrm{pH}$ at $t=0$ (non- $\mathrm{pH}$ controlled process). Indeed, the initial $\mathrm{pH} 13.4$ used in the buffer declined to $\mathrm{pH}$ 13.0, 12.8 , and 12.5 at initial time $(t=0)$ with 50,100 , and $150 \mathrm{mg} \cdot \mathrm{ml}^{-1}$ of initial biomass, respectively. This affects negatively both the first alkaline extraction and the subsequent enzymatic extraction, due to the lower weakening of the cell wall produced. Additionally, $\mathrm{pH}$ continues diminishing up to the final reaction to reach $\mathrm{pH}$ of $12.0,11.0$, and 10.5 in 50,100 , and $150 \mathrm{mg} \cdot \mathrm{ml}^{-1}$, respectively. This reduction with the time is probably due to the buffering properties of the proteins released, as previously have been reported. Gerde et al. [29] found, using an alkaline extraction at pH 11, a significant decrease of the $\mathrm{pH}$, probably due to the protein dissolution and its buffering effect. In their case, this reduction was mainly due to the buffering effect since the concentration of the biomass suspension used was very low (1\%). Indeed, in that study, at $\mathrm{pH} 13$ and $1 \%$ of biomass suspension, the extracted proteins were not enough to reduce the $\mathrm{pH}$.

Concerning the other variables analysed, the time of the alkaline reaction had a positive effect in the overall protein extraction yield mainly due to its effect in the extraction in the first alkaline reaction. Furthermore, the time and temperature of the second enzymatic reaction had a positive effect since these variables improve enzymatic action of the protease used in the second extraction.

In contrast, in the case of the FAN, increments in the initial biomass concentration had a positive effect because they enhance the action of protease as a consequence of the effect of a higher substrate concentration at the same enzyme dosage. Moreover, the time and temperature of the enzymatic reaction had a significantly positive effect. It is worth to note that, in this case, the time of the alkaline reaction had a positive and significant effect, which suggests that the first alkaline reaction not only affects the first extraction directly but also facilitates subsequently the action of the protease in the second extraction due to the weakening of the cell wall.

The first-order surfaces for both models are shown in Figure 3. In the protein model, the surface shows that the extraction yield decreases notably with biomass concentration, following a next to linear tendency. In contrast, the yield increased with the time of the alkaline reaction, showing a more marked curvature at higher biomass 


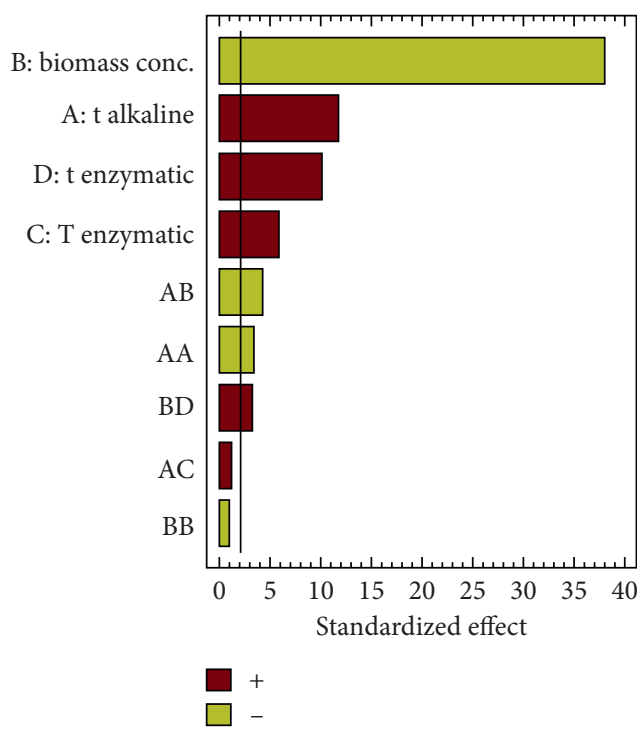

(a)

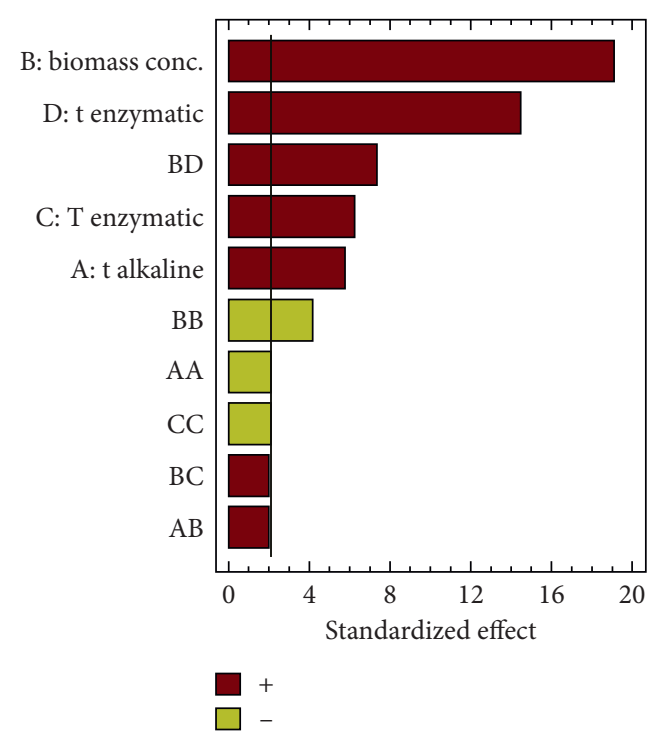

(b)

Figure 2: Pareto diagrams showing the standardized effects of the variables and interactions on the total extraction yield of (a) protein (\% of total protein) and (b) FAN (\% of total biomass).

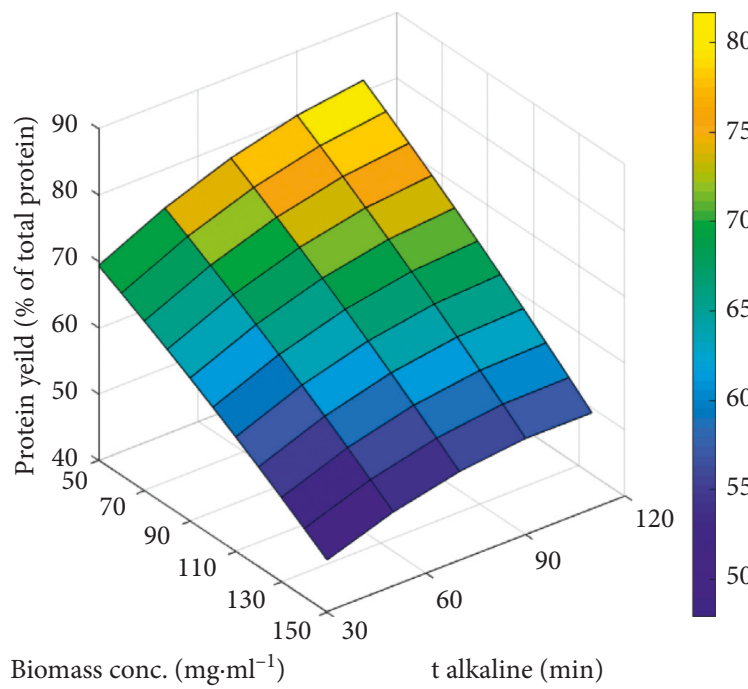

(a)

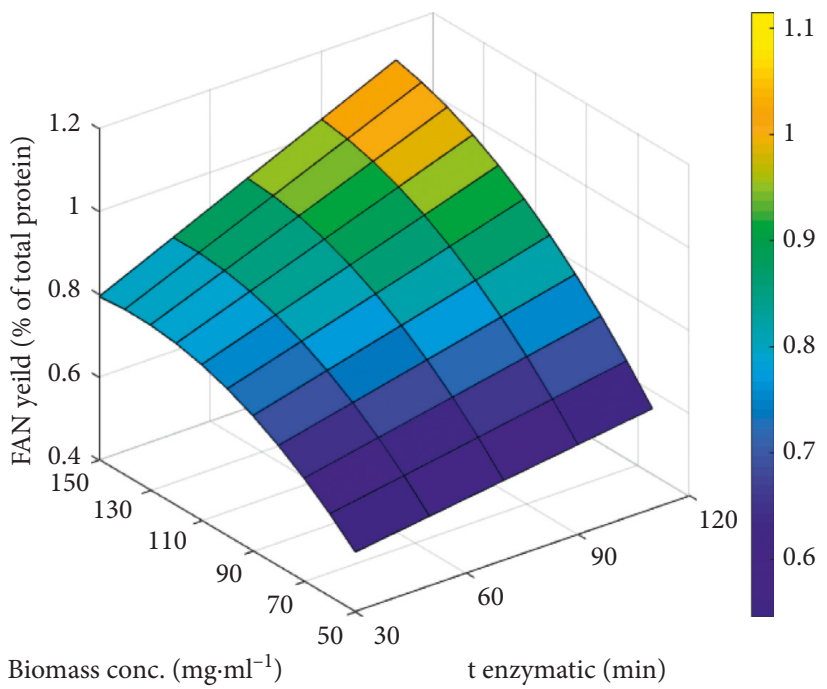

(b)

FIGURE 3: Response surface diagrams showing (a) the effect of the biomass concentration and the time of the alkaline reaction on the protein yield (\% of total protein) $\left(t_{\mathrm{e}}=120 \mathrm{~min}\right.$ and $\left.T_{\mathrm{e}}=60^{\circ} \mathrm{C}\right)$ and $(\mathrm{b})$ the effect of the biomass concentration and the time of the enzymatic reaction on FAN yield (\% of total biomass) $\left(t_{\mathrm{a}}=120 \mathrm{~min}\right.$ and $\left.T_{\mathrm{e}}=60^{\circ} \mathrm{C}\right)$.

concentrations, which indicates that, in higher concentrations, the application of more time in the alkaline reaction is not enough to reach a substantial improvement of the yield. Finally, the maximum protein extraction yield was reached at the minimum biomass concentration $\left(50 \mathrm{mg} \cdot \mathrm{ml}^{-1}\right)$ and maximum alkaline time $(120 \mathrm{~min})$. Furthermore, in the case of FAN model, yield increased with both the biomass concentration and the time of the enzymatic reaction. Nevertheless, while the model showed a curvature for the biomass concentration, the tendency for the time enzymatic reaction was linear in the range studied. Indeed, the maximum FAN extraction yield was achieved at the maximum biomass concentration $\left(150 \mathrm{mg} \cdot \mathrm{ml}^{-1}\right)$ and maximum enzymatic time (120 min).

3.4. Optimization and Validation of the Models. Table 4 shows the optimal values obtained from the models to maximize the response variables. In addition to the protein and FAN models, it includes the optimal of combined response variables. The concentration of the protein in the final extract has also been included in the combined analysis due to its importance in an industrial point of view (model 
TABLE 4: Optimal values of the factors to maximize the different response variables.

\begin{tabular}{|c|c|c|c|c|c|c|c|}
\hline \multirow{2}{*}{\multicolumn{2}{|c|}{ Term }} & \multicolumn{6}{|c|}{ Response variable* } \\
\hline & & $P$ & $F$ & $P+F$ & {$[P]$} & $P+[P]$ & All \\
\hline \multicolumn{2}{|c|}{$\begin{array}{l}\text { Time of the alkaline reaction }\left(t_{\mathrm{a}}\right) \\
(\min )\end{array}$} & 120.0 & 108.0 & 106.0 & 111.3 & 111.2 & 106.7 \\
\hline \multicolumn{2}{|c|}{$\begin{array}{l}\text { Time of the enzymatic reaction } \\
\left(t_{\mathrm{e}}\right)(\mathrm{min})\end{array}$} & 120.0 & 120.0 & 120.0 & 120.0 & 120.0 & 120.0 \\
\hline \multicolumn{2}{|c|}{$\begin{array}{l}\text { Temperature of the enzymatic } \\
\text { reaction }\left(T_{\mathrm{e}}\right)\left({ }^{\circ} \mathrm{C}\right)\end{array}$} & 60.0 & 58.0 & 60.0 & 60.0 & 60.0 & 60.0 \\
\hline \multicolumn{2}{|c|}{$\begin{array}{l}\text { Biomass concentration }\left(B_{\mathrm{c}}\right) \\
\left(\mathrm{mg} \cdot \mathrm{ml}^{-1}\right)\end{array}$} & 50.0 & 150.0 & 102.1 & 150.0 & 104.0 & 121.3 \\
\hline \multirow{3}{*}{ Predicted response } & $P$ & 82.0 & 54.1 & 68.3 & 54.4 & 67.8 & 63.0 \\
\hline & $F$ & 0.66 & 1.16 & 1.02 & 1.17 & 1.02 & 1.09 \\
\hline & {$[P]$} & 8.9 & 15.3 & 14.4 & 16.2 & 14.5 & 15.5 \\
\hline
\end{tabular}

* $P$ : protein yield; $F$ : FAN yield; +: combined optimization; $[P]=$ protein concentration in the final extract; All: combined optimization of $P+F+[P]$.

not shown, with a $\left.R^{2}=0.995\right)$. In all cases, the time and the temperature of the enzymatic extraction obtained the same or close optimal values, $120 \mathrm{~min}$ and $60^{\circ} \mathrm{C}$, respectively, which corresponded to the maximum values established in the experimental design. The time of the alkaline reaction varied among the response variables, with a maximum of $120.0 \mathrm{~min}$ for maximizing the protein extraction yield. The optimal of initial biomass concentration range from the minimum experimental value used $\left(50 \mathrm{mg} \cdot \mathrm{ml}^{-1}\right)$ to the maximum $\left(150 \mathrm{mg} \cdot \mathrm{ml}^{-1}\right)$ for maximizing protein and FAN extraction yields, respectively. Intermediate biomass concentrations of around $100 \mathrm{mg} \cdot \mathrm{ml}^{-1}$ and $120 \mathrm{mg} \cdot \mathrm{ml}^{-1} \mathrm{im}-$ prove yields in combined response variables.

To perform the validation of the models, experiments using the optimal values to maximize the protein yield, except the biomass concentration, were selected $\left(t_{\mathrm{a}}=120 \mathrm{~min}\right.$; $t_{\mathrm{e}}=120 \mathrm{~min} ; T_{\mathrm{e}}=60^{\circ} \mathrm{C}$ ). In the case of the biomass concentration, 50,100 , and $120 \mathrm{mg} \cdot \mathrm{ml}^{-1}$ were chosen because these values were optimal in different combined variables optimizations (Table 4). $150 \mathrm{mg} \cdot \mathrm{ml}^{-1}$ was not selected because this concentration reached a very low yield (54.4\%), which was not sufficiently compensated with the values obtained by the other response variables.

As a result of these experiments, total extraction yields of protein were $80.3,67.5$, and $63.5 \%$ in 50,100 , and $120 \mathrm{mg} \cdot \mathrm{ml}^{-1}$, respectively (Figure 4), compared with the predicted by the model of $82.0,68.9$, and $63.1 \%$, which represent a very good fit since in the worst case, the error was of $2.1 \%$. In the case of FAN, extraction yields reached 0.64 , 0.99 , and $1.07 \%$ in 50,100 , and $120 \mathrm{mg} \cdot \mathrm{ml}^{-1}$, respectively (Figure 4), which were close to the model predicted values of $0.66,1.00$, and $1.08 \%$. The concentrations of protein in the final extracts reached $7.9,13.9$, and $15.2 \mathrm{mg} \cdot \mathrm{ml}^{-1}$ in 50,100 , and $120 \mathrm{mg} \cdot \mathrm{ml}^{-1}$, respectively.

The protein extraction yields obtained in this study through two sequential extractions are higher than those of the previously reported researches with resistant microalgae species using different extraction methods, i.e., $4.4 \%$ by pulsed electric fields [34], 21\% by bead milling [35], 30\% by alkaline extraction [29], 35\% by enzymatic treatment [31] , and $50 \%$ by high-pressure homogenization [30]. Sari et al. [3] also obtained a high yield of $69 \%$ by an enzymatic

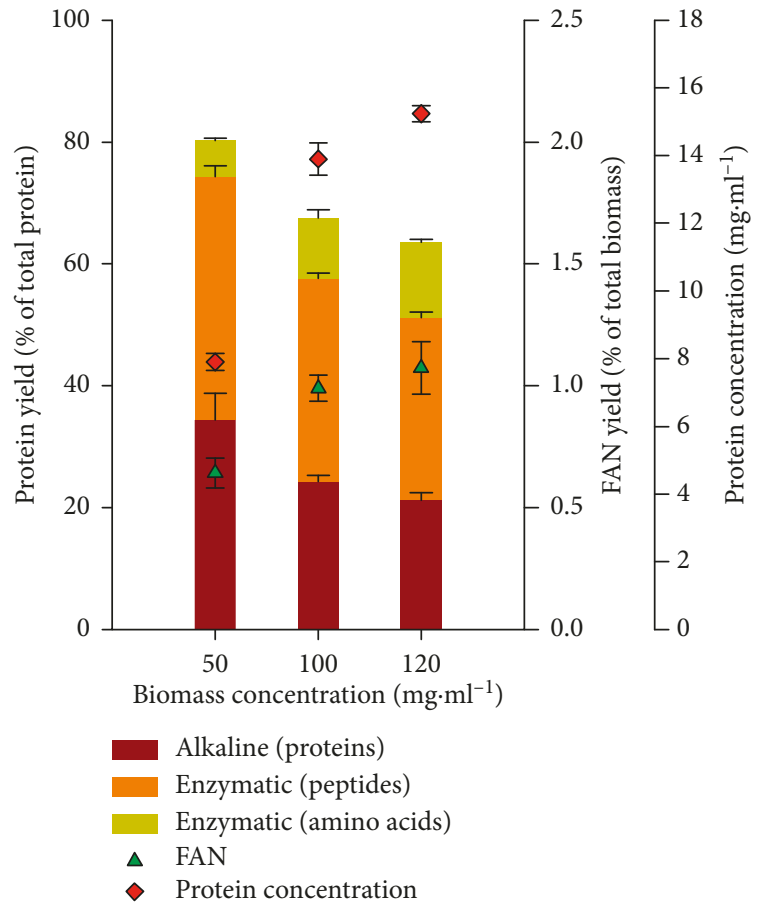

FIGURE 4: Effect of three biomass concentrations on the extraction yields of protein (\% of total protein) and FAN (\% of total biomass) and on the protein concentration in the final extract $\left(\mathrm{mg} \cdot \mathrm{ml}^{-1}\right)$, differencing among first alkaline and second enzymatic extractions.

assisted extraction with proteases, even though using a $\mathrm{pH}$ controlled process.

An electrophoresis using SDS-PAGE was performed to qualitatively evaluate the proteins and peptides existing in the two extracts and to determine their molecular weights (Figure S1). In the alkaline extract, proteins comprised all the range of molecular weights, including high-weight proteins around $250 \mathrm{kDa}$, in accordance with previous studies using alkaline solutions, i.e., at $\mathrm{pH} 11$ [29] and $\mathrm{pH} 12$ [36]. In particular, the band around $17 \mathrm{kDa}$ showed a slight lower dye intensity even though below this molecular weight, the intensity notably increased. This higher intensity between 11 and $17 \mathrm{kDa}$ is similar to that obtained in the mentioned studies using lower 
$\mathrm{pH}$; therefore, it could not be associated to a significant higher degradation of the proteins as a consequence of the high alkaline treatment. In contrast, in the enzymatic extract, the presence of proteins was practically inexistent, except in a slight band with a higher intensity around $11 \mathrm{kDa}$, due to the hydrolysis to small peptides and amino acids with lower molecular weights. This is in accordance with a previous research using a protease for extracting proteins from microalgae, in which the bulk of the peptides obtained comprised molecular weights lower than $12 \mathrm{kDa}$ [37].

The quality of the different extracts should be also further investigated depending on the specific application. The first alkaline treatment can affect the protein properties by denaturation, racemization, and lysinoalanine formation, which could hinder the development of some applications depending on the degree of the affectation, such as emulsifying or foaming substances. Peptides from the enzymatic extract are especially interesting for benefits such as use as bioactive molecules, fertilizers, and culture medium of microorganisms, among others.

\section{Conclusions}

This study provides an alternative approach to obtain protein and amino acids from fresh biomass of resistant microalgae with a high yield. The response surface methodology used has revealed the main effects of the variables affecting the sequential alkaline-enzymatic process and to build models to predict the response of the method. The different existing options identified to maximize not only the response variables individually but also different combination of them provide a high versatility to the method. Indeed, because the biomass concentration is the most important factor affecting the overall process, different results can be obtained by only modifying this variable. A maximum protein yield of $80.3 \%$ is obtained using a concentration of biomass of $50 \mathrm{mg} \cdot \mathrm{ml}^{-1}$, at the expense of FAN yield $(0.64 \%)$ or protein concentration in the final extract $\left(7.9 \mathrm{mg} \cdot \mathrm{ml}^{-1}\right)$. In an intermediate value of biomass concentration $\left(100 \mathrm{mg} \cdot \mathrm{ml}^{-1}\right)$, the yields reach $67.5 \%$ and $0.99 \%$ of protein and FAN, respectively, and the concentration of protein in the final extract achieves $13.9 \mathrm{mg} \cdot \mathrm{ml}^{-1}$. Furthermore, this study has revealed other factors that could be further investigated such as using a sequential alkaline-enzymatic method with a single final extraction, testing the process over other recalcitrant microalgae species, and the control of the $\mathrm{pH}$ of the process, as well as the quality and suitability of the products obtained through the method proposed for different applications.

\section{Data Availability}

The data used to support the findings of this study are included within the article.

\section{Conflicts of Interest}

The authors declare that there are no conflicts of interest regarding the publication of this paper.

\section{Acknowledgments}

The Spanish Government (Ministerio de Economía y Competitividad) provided financial support through the project "Enhancement of landfill gas by an integrated biological system (Biointegra3)" (CTM2016-79089-R).

\section{Supplementary Materials}

Figure S1. SDS-PAGE of the different extracts obtained by the sequential alkaline-enzymatic process, with separate extractions and non-controlled $\mathrm{pH}$, using fresh biomass at a concentration of $100 \mathrm{mg} \cdot \mathrm{ml}^{-1}$. (Supplementary Materials)

\section{References}

[1] E. W. Becker, "Micro-algae as a source of protein," Biotechnology Advances, vol. 25, no. 2, pp. 207-210, 2007.

[2] B. M. Plaza, C. Gómez-Serrano, F. G. Acién-Fernández, and S. Jimenez-Becker, "Effect of microalgae hydrolysate foliar application (Arthrospira platensis and Scenedesmus sp.) on Petunia x hybrida growth," Journal of Applied Phycology, vol. 30, no. 4, pp. 2359-2365, 2018.

[3] Y. W. Sari, M. E. Bruins, and J. P. M. Sanders, "Enzyme assisted protein extraction from rapeseed, soybean, and microalgae meals," Industrial Crops and Products, vol. 43, no. 1, pp. 78-83, 2013.

[4] J. Stack, A. V. Le Gouic, P. R. Tobin, F. Guihéneuf, D. B. Stengel, and R. J. FitzGerald, "Protein extraction and bioactive hydrolysate generation from two microalgae, Porphyridium purpureum and Phaeodactylum tricornutum," Journal of Food Bioactives.vol. 1, pp. 153-165, 2018.

[5] F. G. Acién, E. Molina, J. M. Fernández-Sevilla et al., "20economics of microalgae production," in Woodhead Publishing Series in Energy, C. Gonzalez-Fernandez and R. B. T.-M.-B. B. Muñoz, Eds., pp. 485-503, Woodhead Publishing, Cambridge, UK, 2017.

[6] M. A. Borowitzka, "High-value products from microalgaetheir development and commercialisation," Journal of Applied Phycology, vol. 25, no. 3, pp. 743-756, 2013.

[7] P. Spolaore, C. Joannis-Cassan, E. Duran, and A. Isambert, "Commercial applications of microalgae," Journal of Bioscience and Bioengineering, vol. 101, no. 2, pp. 87-96, 2006.

[8] E. Molina Grima, E.-H. Belarbi, F. G. Acién Fernández, A. Robles Medina, and Y. Chisti, "Recovery of microalgal biomass and metabolites: process options and economics," Biotechnology Advances, vol. 20, no. 7-8, pp. 491-515, 2003.

[9] F. G. Acién, J. M. Fernández, and E. Molina-Grima, "Chapter 14-economics of microalgae biomass production," in Biofules from Algae, A. Pandey, D.-J. Lee, Y. Chisti, and C. R. Soccol, Eds., pp. 313-325, Elsevier, Amsterdam, Netherlands, 2014.

[10] F. G. Acién, J. M. Fernández, J. J. Magán, and E. Molina, "Production cost of a real microalgae production plant and strategies to reduce it," Biotechnology Advances, vol. 30, no. 6, pp. 1344-1353, 2012.

[11] N. Grimi, A. Dubois, L. Marchal, S. Jubeau, N. I. Lebovka, and E. Vorobiev, "Selective extraction from microalgae Nannochloropsis sp. using different methods of cell disruption," Bioresource Technology, vol. 153, pp. 254-259, 2014.

[12] P. R. Postma, T. L. Miron, G. Olivieri, M. J. Barbosa, R. H. Wijffels, and M. H. M. Eppink, "Mild disintegration of the green microalgae Chlorella vulgaris using bead milling," Bioresource Technology, vol. 184, pp. 297-304, 2015. 
[13] C. Safi, L. Cabas Rodriguez, W. J. Mulder et al., "Energy consumption and water-soluble protein release by cell wall disruption of Nannochloropsis gaditana," Bioresource Technology, vol. 239, pp. 204-210, 2017.

[14] E. Barbarino and S. O. Lourenço, "An evaluation of methods for extraction and quantification of protein from marine macro- and microalgae," Journal of Applied Phycology, vol. 17, no. 5, pp. 447-460, 2005.

[15] T. Rausch, "The estimation of micro-algal protein content and its meaning to the evaluation of algal biomass I. Comparison of methods for extracting protein," Hydrobiologia, vol. 78, no. 3, pp. 237-251, 1981.

[16] S. P. Slocombe, M. Ross, N. Thomas, S. McNeill, and M. S. Stanley, "A rapid and general method for measurement of protein in micro-algal biomass," Bioresource Technology, vol. 129, pp. 51-57, 2013.

[17] J. M. Romero García, F. G. Acién Fernández, and J. M. Fernández Sevilla, "Development of a process for the production of 1-amino-acids concentrates from microalgae by enzymatic hydrolysis," Bioresource Technology, vol. 112, pp. 164-170, 2012.

[18] S. S. Kilham, D. a. Kreeger, S. G. Lynn, C. E. Goulden, and L. Herrera, "COMBO: A defined freshwater culture medium for algae and zooplankton," Hydrobiologia, vol. 377, no. 1-3, pp. 147-159, 1998.

[19] L. S. Clesceri, A. E. Greenberg, and A. D. Eaton, Standard Methods for the Examination of Water and Wastewater, American Public Health Association/American Water Works Association/Water Environment Federation., Washington, DC, USA, 20th edition, 1999.

[20] V. S. Stoll and J. S. Blanchard, "Chapter 6 buffers. Principles and practice 1," Methods in Enzymology, vol. 463, pp. 43-56, 2009.

[21] J. Mosse, "Nitrogen-to-protein conversion factor for ten cereals and six legumes or oilseeds. A reappraisal of its definition and determination. Variation according to species and to seed protein content," Journal of Agricultural and Food Chemistry, vol. 38, no. 1, pp. 18-24, 1990.

[22] M. E. Watson and T. L. Galliher, "Comparison of Dumas and Kjeldahl methods with automatic analyzers on agricultural samples under routine rapid analysis conditions," Communications in Soil Science and Plant Analysis, vol. 32, no. 13-14, pp. 2007-2019, 2001.

[23] R. L. Heinrikson and S. C. Meredith, "Amino acid analysis by reverse-phase high-performance liquid chromatography: precolumn derivatization with phenylisothiocyanate," Analytical Biochemistry, vol. 136, no. 1, pp. 65-74, 1984.

[24] O. H. Lowry, N. J. Rosebrough, A. L. Farr, and R. J. Randall, "Protein measurement with the folin phenol reagent," Journal of Biological Chemistry, vol. 193, no. 1, pp. 265-275, 1951.

[25] A. Bensadoun and D. Weinstein, "Assay of proteins in the presence of interfering materials," Analytical Biochemistry, vol. 70, no. 1, pp. 241-250, 1976.

[26] D. G. Abernathy, G. Spedding, and B. Starcher, "Analysis of protein and total usable nitrogen in beer and wine using a microwell ninhydrin assay," Journal of the Institute of Brewing, vol. 115, no. 2, pp. 122-127, 2009.

[27] S. O. Lourenço, E. Barbarino, P. L. Lavín, U. M. Lanfer Marquez, and E. Aidar, "Distribution of intracellular nitrogen in marine microalgae: calculation of new nitrogen-to-protein conversion factors," European Journal of Phycology, vol. 39, no. 1, pp. 17-32, 2004.

[28] D. W. Templeton and L. M. L. Laurens, "Nitrogen-to-protein conversion factors revisited for applications of microalgal biomass conversion to food, feed and fuel," Algal Research, vol. 11, no. 3, pp. 359-367, 2015.

[29] J. A. Gerde, T. Wang, L. Yao, S. Jung, L. A. Johnson, and B. Lamsal, "Optimizing protein isolation from defatted and non-defatted Nannochloropsis microalgae biomass," Algal Research, vol. 2, no. 2, pp. 145-153, 2013.

[30] C. Safi, A. V. Ursu, C. Laroche et al., "Aqueous extraction of proteins from microalgae: effect of different cell disruption methods," Algal Research, vol. 3, no. 1, pp. 61-65, 2014.

[31] C. Safi, G. Olivieri, R. P. Campos et al., "Biorefinery of microalgal soluble proteins by sequential processing and membrane filtration," Bioresource Technology, vol. 225, pp. 151-158, 2017.

[32] M. J. Scholz, T. L. Weiss, R. E. Jinkerson et al., "Ultrastructure and composition of the Nannochloropsis gaditana cell wall," Eukaryotic Cell, vol. 13, no. 11, pp. 1450-1464, 2014.

[33] D. E. Schwass and J. W. Finley, "Heat and alkaline damage to proteins: racemization and lysinoalanine formation," Journal of Agricultural and Food Chemistry, vol. 32, no. 6, pp. 13771382, 1984.

[34] P. R. Postma, G. Pataro, M. Capitoli et al., "Selective extraction of intracellular components from the microalga Chlorella vulgaris by combined pulsed electric field-temperature treatment," Bioresource Technology, vol. 203, pp. 80-88, 2016.

[35] A. Schwenzfeier, P. A. Wierenga, and H. Gruppen, "Isolation and characterization of soluble protein from the green microalgae Tetraselmis sp," Bioresource Technology, vol. 102, no. 19, pp. 9121-9127, 2011.

[36] A.-V. Ursu, A. Marcati, T. Sayd, V. Sante-Lhoutellier, G. Djelveh, and P. Michaud, "Extraction, fractionation and functional properties of proteins from the microalgae Chlorella vulgaris," Bioresource Technology, vol. 157, pp. 134-139, 2014.

[37] H. J. Morris, A. Almarales, O. Carrillo, and R. C. Bermúdez, "Utilisation of Chlorellavulgaris cell biomass for the production of enzymatic protein hydrolysates," Bioresource Technology, vol. 99, no. 16, pp. 7723-7729, 2008. 

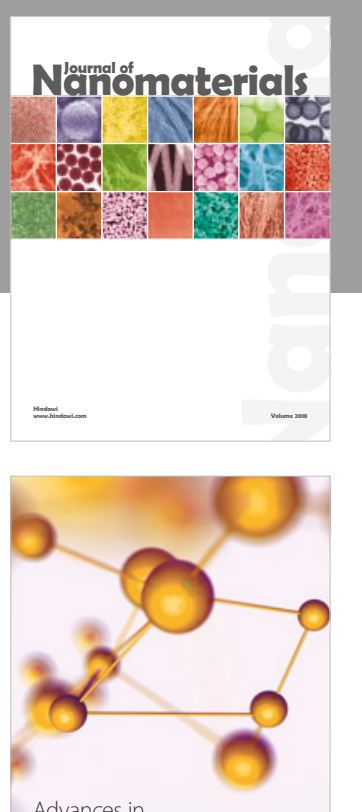

Physical Chemistry
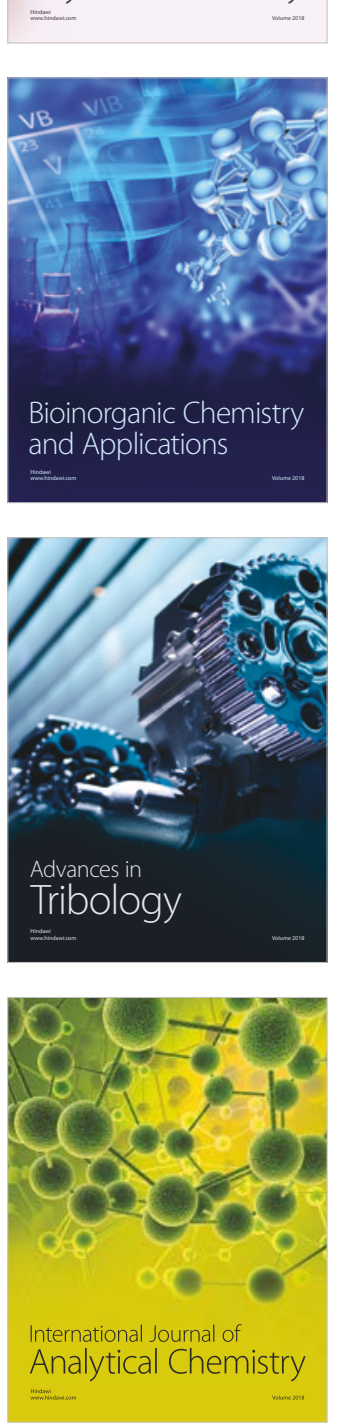

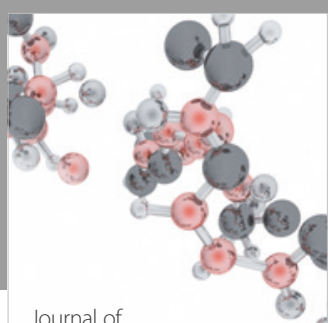

Analytical Methods

in Chemistry

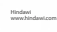

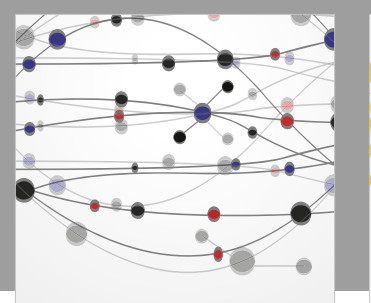

The Scientific World Journal

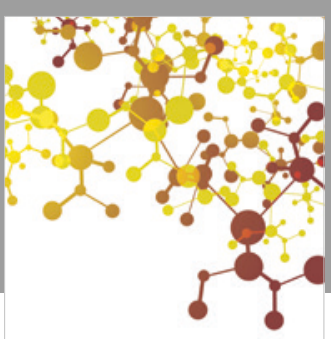

Journal of

Applied Chemistry
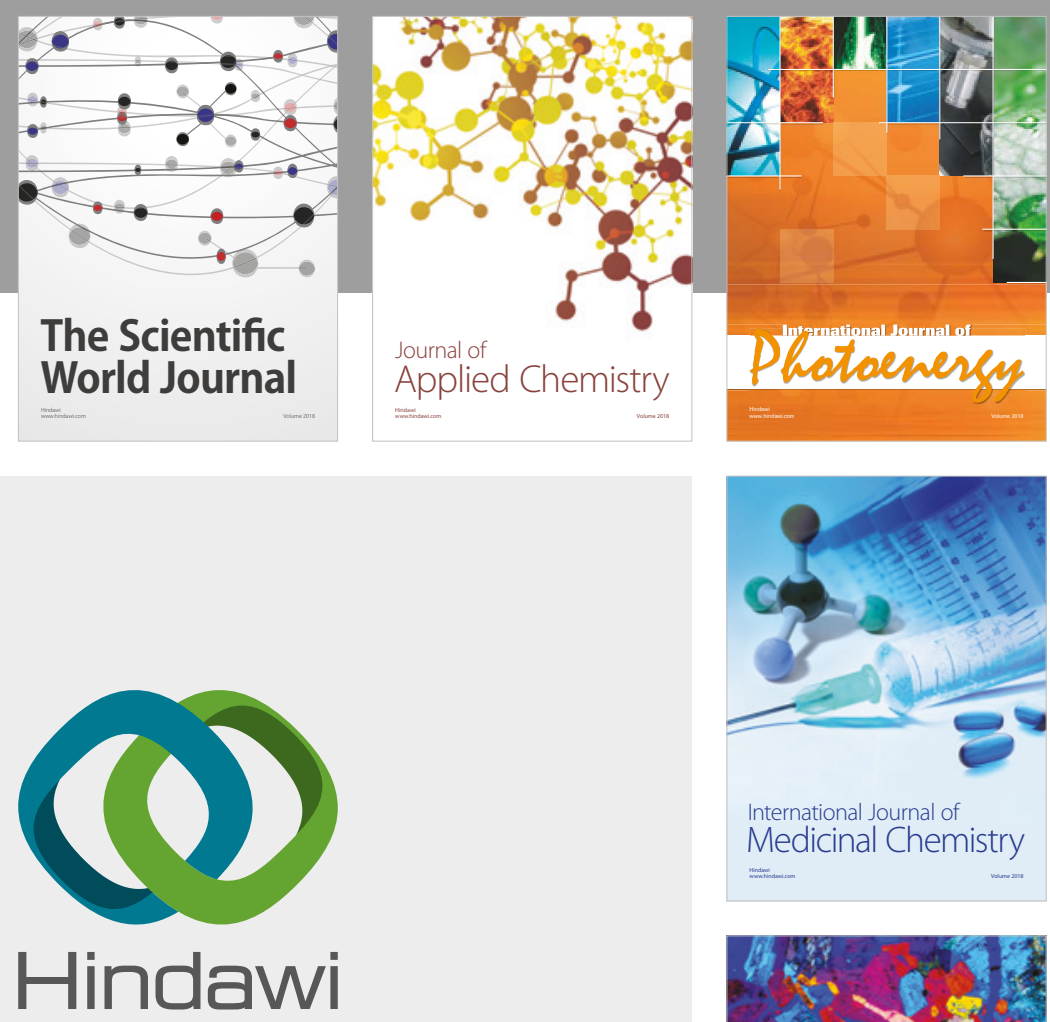

Submit your manuscripts at

www.hindawi.com
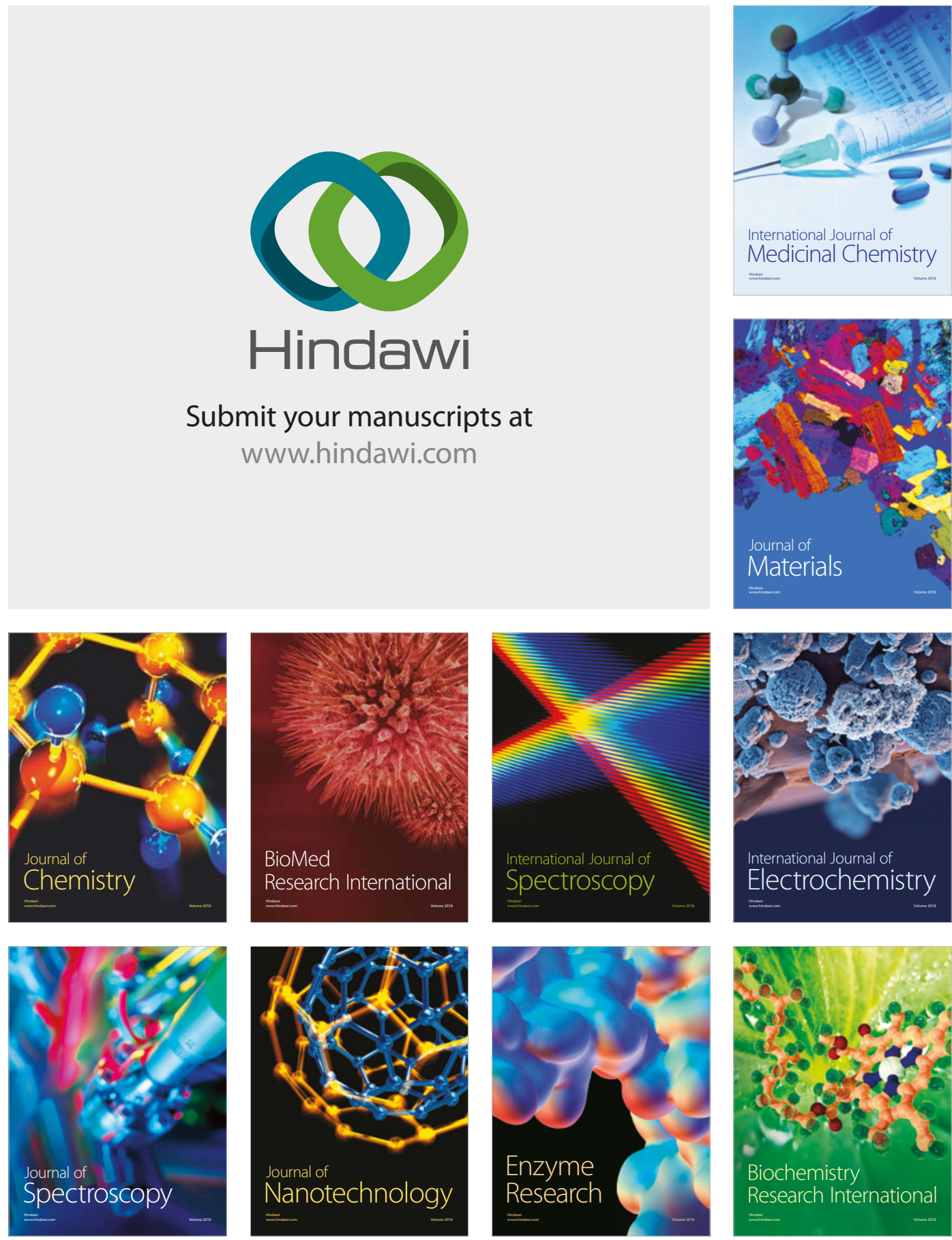
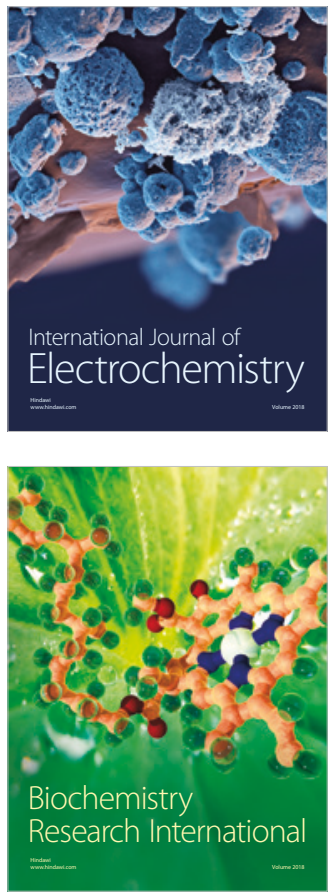